
\title{
$\begin{array}{ll}\text { Research Square } & \begin{array}{l}\text { Preprints are preliminary reports that have not undergone peer review. } \\ \text { They should not be considered conclusive, used to inform clinical practice, } \\ \text { or referenced by the media as validated information. }\end{array}\end{array}$
}

\section{The Prognostic Influence of Venous Thromboembolism in Non-Small Cell Lung Cancer: A Meta-Analysis and Systematic Review}

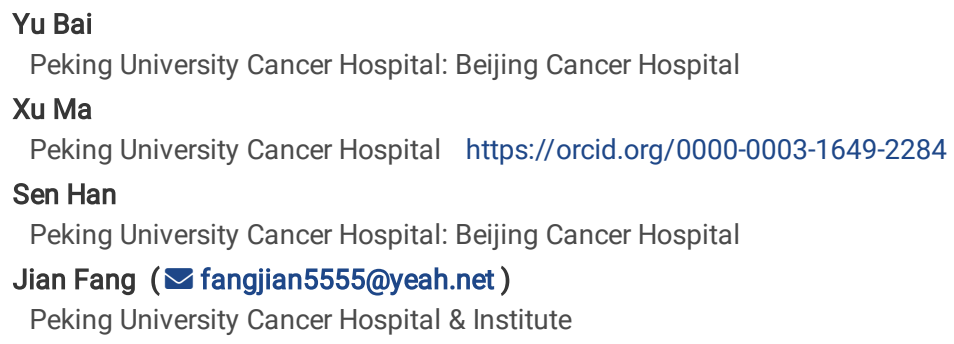

\section{Research}

Keywords: Meta-analysis, non-small cell lung cancer, overall survival, venous thromboembolism, prognosis

Posted Date: November 13th, 2020

DOI: https://doi.org/10.21203/rs.3.rs-104502/v1

License: (9) (1) This work is licensed under a Creative Commons Attribution 4.0 International License. Read Full License 


\section{Abstract}

Background: Patients with non-small cell lung cancer (NSCLC) have a significantly higher risk of developing venous thromboembolism (VTE), a condition that significantly influences the prognosis of these patients. However, the impact of VTE on the survival of NSCLC patients remains unclear. We aim to evaluate the impact of VTE on the mortality of patients with NSCLC.

Methods: We systematically reviewed all indexed studies examining the prognosis of NSCLC patients with VTE. Web of Science, EMBASE, PubMed, and the Cochrane Library were searched through December 31, 2019 to identify relevant studies. Fixed- or random-effects models were chosen based on heterogeneity.

Results: Twelve articles with 6480 patients were included in this analysis. The heterogeneity of these studies was significant $(R=81 \%, P<0.01)$. The overall survival (OS) of NSCLC patients with VTE was shorter compared to patients without VTE (HR=1.71, 95\% Cl [1.39-2.10], $P<0.01)$. Two small groups of SCLC patients were excluded and the remaining patients were divided into the Asian and non-Asian groups. The Asian group showed low heterogeneity $(P=35 \%$, $P=0.20)$, in which NSCLC patients with VTE also had shorter OS (HR=1.49, 95\% $\mathrm{Cl}[1.19-1.88], P<0.01)$.

Conclusions: VTE is significantly associated with a shorter OS of NSCLC patients, especially in Asian patients. Proper prevention and management of VTE is the key to improving the survival of patients with NSCLC.

\section{Introduction}

The association between cancer and venous thromboembolism (VTE) was first identified in 1865 [1]. VTE is a medical condition that includes deep vein thrombosis (DVT), pulmonary embolism (PE), and Trousseau syndrome (migratory thrombophlebitis). Approximately $20 \%$ of VTE cases occur in cancer patients [2,3]. Moreover, cancer-associated VTE is more aggressive and usually associated with worse prognosis [4].

Lung cancer is one of the most common cancers worldwide with a 5-year survival rate of only $19 \%[5,6]$. Non-small cell lung cancer (NSCLC) accounts for $80-$ $85 \%$ of the lung cancer cases [7]. The incidence of VTE in NSCLC patients is $7.3-13.6 \%[8,9]$. VTE in cancer patients, including NSCLC patients, may lead to devastating consequences, including thrombotic events, treatment-related bleeding, delay in chemotherapy, and drug interactions [10].

Cancer patients with VTE have up to three times higher risk of one-year mortality compared to those at the same stage of the disease but without thrombosis $[4,11]$. Specifically, lung cancer patients with DVT have a 1.29-fold higher risk of mortality compared to those without thrombotic events $(95 \%$ Cl:1.12-1.48) [12]. Most large cohort studies investigated the general population with cancer rather than NSCLC patients. The prognostic influence of VTE can only be evaluated through subgroup analysis. However, previous studies mainly focused on more specific subgroups, such as lung cancer patients with PE [13], patients with early-staged or resectable NSCLC[14], and lung cancer patients with preventive anticoagulation [15]. Many oncologists pay attention to the treatment of the tumor itself, lack of awareness of VTE, meanwhile, the treatment strategies of NSCLC have been emerging in recent years, there is need to evaluate and update the understanding of the prognostics of NSCLC with VTE. Therefore, a meta-analysis was performed in this study to investigate the impact of VTE on the survival of NSCLC patients by comparing the overall survival (OS) between NSCLC patients with and without VTE. We further discussed the importance of VTE management and prevention in improving the prognosis of NSCLC patients.

\section{Methods}

Literature search

A comprehensive systematic search was performed in four major databases (Web of Science, EMBASE, PubMed, and Cochrane Library) on December 31, 2019. The following terms were used: ["non-small cell lung cancer" OR "NSCLC"] AND ["venous thromboembolism" OR "VTE" OR "deep vein thrombosis" OR "DVT" OR "pulmonary thromboembolism" OR “PE”]. We reviewed the reference lists of included studies for additional screening.

\section{Study selection}

The inclusion criteria for screening studies were: (1) study population was NSCLC patients complicated with VTE; (2) the control group was NSCLC patients without VTE; (3) endpoints included OS or progression-free survival (PFS); (4) a Newcastle-Ottawa Scale (NOS) score of >5 points.

Studies were excluded if (1) there was no control group or the control group was not non-VTE NSCLC patients; (2) the endpoint was not PFS or OS; (3) not published in English; (4) published in the format of review articles, short survey, case report, meeting reports, or grey literature; (5) repeated previous findings; (6) only reported non-clinical results.

\section{Date extraction and literature evaluation}

Two investigators (YB and XM) independently reviewed the titles and abstracts of the articles and then selected potentially relevant studies based on the inclusion/exclusion criteria. Data were extracted using a standardized form and categorized as follows: name of the first author, year of publication, research type, number of eligible patients, classification of NSCLC, pathological typing of NSCLC, age, sex, and endpoints. Finally, the extracted data were crosschecked and any discrepancies were discussed with a third investigator. Each included article was evaluated for the risk of bias using a modified version of the NOS. Only high-quality articles with a score of greater than 5 were selected.

\section{Statistical analysis}


RevMan 5.3 (The Cochrane Collaboration, London, UK) was used for analysis. The heterogeneity was evaluated by the Q test and the $P$ test metric [16]. Heterogeneity was considered to be present when $p<0.1$ and ${ }^{2}>50 \%$. A random-effects model was then selected to calculate pooled hazard ratio (HR) and 95\% confidence interval $(\mathrm{Cl})$ with a forest plot. When heterogeneity was not present, a fixed-effects model was used to estimate pooled HR and $95 \% \mathrm{Cl}$. KaplanMeier survival curves were read by Engauge Digitizer (version 12.0) to obtain HR and $95 \% \mathrm{Cl}$ [17]. Publication bias and sensitivity analysis were performed using STATA 15.0 (StataCorp LLC, College Station, USA).

\section{Results}

\section{Search result}

Of the 5,096 studies identified by the search strategy, 2,574 remained after eliminating duplicates. Of these, 2,550 were excluded after screening the titles and abstracts, leaving 24 articles for full-text review. Twelve articles were further excluded after full-text screening following the inclusion/exclusion criteria. Finally, twelve articles were included in the analysis. The screening process was summarized in Fig. 1.

\section{Characteristics of included studies}

Of the 12 articles, two included a small group of patients with small-cell lung cancer (SCLC) [18][19], whereas the rest only recruited NSCLC patients [9, 14, 2027]. All studies compared the OS between NSCLC patients with and without VTE. Four of them were prospective observational cohort studies [14, 20, 22, 27] and the remaining eight were retrospective studies $[9,18,19,21,23-26]$. All included articles were of high quality (Table 1). 
Table 1

Main characteristics of the included studies.

\begin{tabular}{|c|c|c|c|c|c|c|c|c|c|c|c|c|}
\hline Study & $\begin{array}{l}\text { Year of } \\
\text { publication }\end{array}$ & Country & Study type & Group & $\begin{array}{l}\text { Number } \\
\text { of } \\
\text { patients }\end{array}$ & $\begin{array}{l}\text { Lung } \\
\text { cancer } \\
\text { type } \\
\text { (number) }\end{array}$ & $\begin{array}{l}\text { Histologic types } \\
\text { of lung cancer } \\
\text { (number) }\end{array}$ & $\begin{array}{l}\text { Age } \\
\text { (years) }\end{array}$ & Gender & $\begin{array}{l}\text { Staging } \\
\text { (number) }\end{array}$ & Endpoint & $\uparrow$ \\
\hline \multirow[t]{2}{*}{$\begin{array}{l}\text { de Meis } \\
\text { et al. }\end{array}$} & \multirow[t]{2}{*}{2009} & \multirow[t]{2}{*}{ Brazil } & \multirow[t]{2}{*}{$\begin{array}{l}\text { Prospective } \\
\text { cohort }\end{array}$} & VTE & 26 & \multirow[t]{2}{*}{$\begin{array}{l}\text { NSCLC } \\
(109)\end{array}$} & \multirow[t]{2}{*}{ Adenocarcinomas } & \multirow{2}{*}{$\begin{array}{l}60 \\
(43- \\
80)\end{array}$} & \multirow[t]{2}{*}{$\begin{array}{l}M / F \\
71 / 38\end{array}$} & $\begin{array}{l}\text { I and II } \\
(20)\end{array}$ & \multirow[t]{2}{*}{ OS } & \multirow[t]{2}{*}{7} \\
\hline & & & & $\begin{array}{l}\text { Non- } \\
\text { VTE }\end{array}$ & 83 & & & & & $\begin{array}{l}\text { III and IV } \\
\text { (89) }\end{array}$ & & \\
\hline \multirow{7}{*}{$\begin{array}{l}\text { Hicks et } \\
\text { al. }\end{array}$} & \multirow[t]{7}{*}{2009} & \multirow[t]{7}{*}{ Canada } & \multirow{2}{*}{$\begin{array}{l}\text { Retrospective } \\
\text { cohort (BR. } \\
\text { 10) }\end{array}$} & VTE & 10 & \multirow{7}{*}{$\begin{array}{l}\text { NSCLC } \\
(1987)\end{array}$} & Adenocarcinoma & \multirow[t]{7}{*}{ NG } & \multirow[t]{7}{*}{ NG } & I (219) & \multirow[t]{7}{*}{ os } & 7 \\
\hline & & & & $\begin{array}{l}\text { Non- } \\
\text { VTE }\end{array}$ & 472 & & Squamous & & & II (263) & & \\
\hline & & & \multirow{3}{*}{$\begin{array}{l}\text { Retrospective } \\
\text { cohort (BR. } \\
18)\end{array}$} & VTE & 81 & & \multirow[t]{5}{*}{ Others } & & & Illa (1) & & \\
\hline & & & & Non- & 693 & & & & & IIIb (164) & & \\
\hline & & & & VTE & & & & & & IV (1036) & & \\
\hline & & & \multirow{2}{*}{$\begin{array}{l}\text { Retrospective } \\
\text { cohort (BR. } \\
21 \text { ) }\end{array}$} & VTE & 42 & & & & & & & \\
\hline & & & & $\begin{array}{l}\text { Non- } \\
\text { VTE }\end{array}$ & 689 & & & & & & & \\
\hline \multirow{10}{*}{$\begin{array}{l}\text { Lee et } \\
\text { al. }\end{array}$} & \multirow[t]{10}{*}{2009} & \multirow[t]{10}{*}{ Korea } & \multirow{10}{*}{$\begin{array}{l}\text { Retrospective } \\
\text { cohort }\end{array}$} & \multirow[t]{5}{*}{$\mathrm{PE}$} & 40 & NSCLC & Adenocarcinoma & $63.7 \pm$ & $\mathrm{M} / \mathrm{F}$ & $\mathrm{lb}(1)$ & OS & 7 \\
\hline & & & & & & $\operatorname{SCLC}(9)$ & $\begin{array}{l}\text { Squamous } \\
\text { LCNEC }\end{array}$ & & & $\mathrm{Ilb}(2)$ & & \\
\hline & & & & & & & $\mathrm{SCLC}$ & & & IIla (4) & & \\
\hline & & & & & & & & & & IIIb (16) & & \\
\hline & & & & & & & & & & IV (17) & & \\
\hline & & & & $\begin{array}{l}\text { Non- } \\
\text { PE }\end{array}$ & 80 & $\begin{array}{l}\text { NSCLC } \\
(62)\end{array}$ & & $\begin{array}{l}63.0 \pm \\
8.82\end{array}$ & $\begin{array}{l}M / F \\
60 /\end{array}$ & $\mathrm{lb}(2)$ & & \\
\hline & & & & & & $\begin{array}{l}\text { ŚCĹC } \\
(18)\end{array}$ & & & & Ill (4) & & \\
\hline & & & & & & & & & & Illa (6) & & \\
\hline & & & & & & & & & & IIIb (34) & & \\
\hline & & & & & & & & & & IV (34) & & \\
\hline Zhang & 2013 & China & Retrospective & VTE & NG & NSCLC & Adenocarcinoma & 61 & $\mathrm{M} / \mathrm{F}$ & I and || & OS & 7 \\
\hline & & & & $\begin{array}{l}\text { Non- } \\
\text { VTE }\end{array}$ & NG & & Squamous & 86) & 83 & Illa (59) & & \\
\hline Kourelis & 2014 & USA & Retrospective & VTE & 44 & NSCLC & NSCLC & 68 & $\mathrm{M} / \mathrm{F}$ & I (3) & os & 7 \\
\hline & & & & & & SCLC (6) & SCLC & 91) & 21 & Illa (5) & & \\
\hline & & & & & & & Other & & & IIIb (4) & & \\
\hline & & & & & & & & & & IV (24) & & \\
\hline & & & & $\begin{array}{l}\text { Non- } \\
\text { VTE }\end{array}$ & 683 & $\begin{array}{l}\text { NSCLC } \\
(594)\end{array}$ & & $\begin{array}{l}69 \\
(30-\end{array}$ & $\begin{array}{l}M / F \\
353 /\end{array}$ & I (209) & & \\
\hline & & & & & & & & 95) & 330 & II (38) & & \\
\hline & & & & & & Other (3) & & & & IIla (63) & & \\
\hline & & & & & & & & & & IIIb (60) & & \\
\hline & & & & & & & & & & IV (207) & & \\
\hline $\begin{array}{l}\text { Chen et } \\
\text { al. }\end{array}$ & 2015 & China & $\begin{array}{l}\text { Prospective } \\
\text { cohort }\end{array}$ & VTE & 56 & $\begin{array}{l}\text { NSCLC } \\
(94)\end{array}$ & $\begin{array}{l}\text { Adenocarcinoma } \\
\text { (20) }\end{array}$ & $\begin{array}{l}62 \pm \\
11\end{array}$ & $\begin{array}{l}M / F \\
39 /\end{array}$ & $\begin{array}{l}\text { I and II } \\
\text { (29) }\end{array}$ & OS & 7 \\
\hline & & & & & & & Squamous (36) & & & IIIb (27) & & \\
\hline
\end{tabular}




\begin{tabular}{|c|c|c|c|c|c|c|c|c|c|c|c|c|}
\hline \multirow[t]{3}{*}{ Study } & \multirow[t]{3}{*}{$\begin{array}{l}\text { Year of } \\
\text { publication }\end{array}$} & \multirow[t]{3}{*}{ Country } & \multirow[t]{3}{*}{ Study type } & \multirow{3}{*}{$\begin{array}{l}\text { Group } \\
\begin{array}{l}\text { Non- } \\
\text { VTE }\end{array}\end{array}$} & \multirow[t]{3}{*}{$\begin{array}{l}\text { Number } \\
\text { of } \\
\text { patients }\end{array}$} & \multirow[t]{3}{*}{$\begin{array}{l}\text { Lung } \\
\text { cancer } \\
\text { type } \\
\text { (number) }\end{array}$} & $\begin{array}{l}\text { Histologic types } \\
\text { of lung cancer } \\
\text { (number) }\end{array}$ & \multirow[t]{3}{*}{$\begin{array}{l}\text { Age } \\
\text { (years) }\end{array}$} & \multirow{3}{*}{$\begin{array}{l}\text { Gender } \\
\text { M/F } \\
26 / / \\
12\end{array}$} & $\begin{array}{l}\text { Staging } \\
\text { (number) }\end{array}$ & \multirow[t]{3}{*}{ Endpoint } & \multirow[t]{3}{*}{ i } \\
\hline & & & & & & & $\begin{array}{l}\text { Adenocarcinoma } \\
\text { (11) }\end{array}$ & & & $\begin{array}{l}\text { I and II } \\
(25)\end{array}$ & & \\
\hline & & & & & & & Squamous (27) & & & IIIb (13) & & \\
\hline \multirow{4}{*}{$\begin{array}{l}\text { Wang } \\
\text { et al. }\end{array}$} & \multirow[t]{4}{*}{2015} & \multirow[t]{4}{*}{ China } & \multirow{4}{*}{$\begin{array}{l}\text { Prospective } \\
\text { cohort }\end{array}$} & \multirow[t]{2}{*}{ VTE } & \multirow[t]{2}{*}{61} & \multirow{4}{*}{$\begin{array}{l}\text { NSCLC } \\
(94)\end{array}$} & \multirow[t]{4}{*}{ NG } & \multirow{2}{*}{$\begin{array}{l}58.9 \pm \\
11.6\end{array}$} & \multirow{2}{*}{$\begin{array}{l}\mathrm{M} / \mathrm{F} \\
39 / \\
22\end{array}$} & I - IIIa (2) & \multirow[t]{4}{*}{ os } & \multirow[t]{4}{*}{7} \\
\hline & & & & & & & & & & $\begin{array}{l}\text { Illlb - IV } \\
(59)\end{array}$ & & \\
\hline & & & & \multirow{2}{*}{$\begin{array}{l}\text { Non- } \\
\text { VTE }\end{array}$} & \multirow[t]{2}{*}{122} & & & \multirow{2}{*}{$\begin{array}{l}60.9 \pm \\
12.1\end{array}$} & \multirow{2}{*}{$\begin{array}{l}M / F \\
85 / \\
37\end{array}$} & I - IIIla (4) & & \\
\hline & & & & & & & & & & $\begin{array}{l}\text { IIIb - IV } \\
(118)\end{array}$ & & \\
\hline \multirow[t]{4}{*}{ Li et al. } & 2016 & USA & Retrospective & VTE & 97 & $\begin{array}{l}\text { NSCLC } \\
(629)\end{array}$ & Adenocarcinoma & $\begin{array}{l}64 \\
(28-\end{array}$ & $\mathrm{M} / \mathrm{F}$ & Ila (37) & & \\
\hline & & & & Non- & 532 & & Squamous (181) & & & (ID) & OS, PFS & 7 \\
\hline & & & & VIE & & & Other (121) & & & IIId (000) & & \\
\hline & & & & & & & & & & IIllb (207) & & \\
\hline $\begin{array}{l}\text { Shen et } \\
\text { al. }\end{array}$ & 2017 & China & $\begin{array}{l}\text { Retrospective } \\
\text { cohort }\end{array}$ & VTE & 32 & NSCLC & NG & $60.3 \pm$ & $\mathrm{M} / \mathrm{F}$ & III (14) & os & 7 \\
\hline & & & & & & & & & & IV (18) & & \\
\hline & & & & $\begin{array}{l}\text { Non- } \\
\text { VTTE }\end{array}$ & 96 & & & $60.6 \pm$ & $\mathrm{M} / \mathrm{F}$ & III (42) & & \\
\hline & & & & & & & & & & IV (54) & & \\
\hline Zer et & 2017 & Mixed & Retrospective & VTE & 35 & NSCLC & NG & 52 & $\mathrm{M} / \mathrm{F}$ & II (3) & os & 7 \\
\hline & & & & & & & & $79)$ & 30 & III (4) & & \\
\hline & & & & & & & & & & IV (28) & & \\
\hline & & & & Non- & 63 & & & 58 & $\mathrm{M} / \mathrm{F}$ & I (9) & & \\
\hline & & & & & & & & 94) & 30 & II (2) & & \\
\hline & & & & & & & & & & III (7) & & \\
\hline & & & & & & & & & & IV (45) & & \\
\hline $\begin{array}{l}\text { Young } \\
\text { et al. }\end{array}$ & 2018 & Mixed & $\begin{array}{l}\text { Retrospective } \\
\text { cohort }\end{array}$ & VTE & 1009 & $\begin{array}{l}\text { NSCLC } \\
(1917)\end{array}$ & $\begin{array}{l}\text { squamous (1301) } \\
\text { non-squamous }\end{array}$ & $\begin{array}{l}62 \\
(26- \\
88)\end{array}$ & $\begin{array}{l}\mathrm{M} / \mathrm{F} \\
788 /\end{array}$ & NG & os & 7 \\
\hline & & & & $\begin{array}{l}\text { Non- } \\
\text { VTEE }\end{array}$ & 908 & & & $\begin{array}{l}62 \\
(32- \\
88)\end{array}$ & $\begin{array}{l}M / F \\
700 / \\
201\end{array}$ & & & \\
\hline $\begin{array}{l}\text { Herrero } \\
\text { et al. }\end{array}$ & 2019 & Europe & $\begin{array}{l}\text { Prospective } \\
\text { cohort }\end{array}$ & VTE & NG & $\begin{array}{l}\text { NSCLC } \\
(345)\end{array}$ & $\begin{array}{l}\text { Adenocarcinoma } \\
\text { (124) }\end{array}$ & $\begin{array}{l}67 \\
(31-\end{array}$ & $\begin{array}{l}\mathrm{M} / \mathrm{F} \\
305 /\end{array}$ & $\begin{array}{l}\text { I and II } \\
(20)\end{array}$ & os & 7 \\
\hline & & & & Non- & NG & & Squamous (187) & & & IIla (140) & & \\
\hline & & & & VTE & & & (10) & & & IIIb (140) & & \\
\hline & & & & & & & Other (24) & & & IV (45) & & \\
\hline
\end{tabular}

Abbreviations: VTE, venous thromboembolism; M, male; F, female; PE, pulmonary embolism; NSCLC, non-small cell lung cancer; SCLC, small cell lung cancer; LCNEC, large cell neuroendocrine carcinoma.

\section{Comparison of OS between NSCLC patients with and without VTE}

Twelve studies explored the relationship between VTE and OS in NSCLC patients [9, 14,26, 27, 18-25]. Significant heterogeneity was present in the analysis of OS between VTE and non-VTE NSCLC patients $(R=81 \%, p<0.01)$. Therefore, pooled HR was calculated by a random-effects model. The analysis showed that NSCLC patients with VTE had significantly short OS compared to those without VTE (HR=1.71, 95\% $\mathrm{Cl}[1.39-2.10], p<0.01)($ Fig. 2$)$.

\section{Comparison of OS between NSCLC patients with and without VTE in different subgroups}

As the heterogeneity was high, we further conducted a subgroup analysis. Firstly, we excluded two studies with a small number of SCLC patients [18, 19]. The remaining ten studies $[9,14,20-27]$ were divided into two subgroups according to the race of the study population. Studies in the first subgroup ( $\mathrm{n}=4$ ) compared the OS between Asian NSCLC patients with and without VTE, whereas studies in the second group $(n=6)$ compared the OS between non-Asian patients with and without VTE. The first subgroup was homogeneous $(R=35 \%, p=0.20)$, while the non-Asian subgroup showed significant heterogeneity $(R=$ $74 \%, p<0.01)$. Therefore, a random-effects model was used to evaluate the pooled effect of OS in NSCLC patients (Fig. 3). The meta-analysis demonstrated 
that NSCLC patients with VTE had shorter OS compared to those without VTE (Asian group: $\mathrm{HR}=1.49,95 \% \mathrm{Cl}[1.19-1.88], p<0.01$; non-Asian group: HR = 1.52, 95\% Cl [1.37-1.68], $p<0.01$; Total population: $\mathrm{HR}=1.51,95 \% \mathrm{Cl}[1.38-1.66], p<0.01)$ (Fig. 3).

\section{Publication bias and sensitivity analysis}

The Begg's funnel plot $(p=0.381)$ and Egger's test $(p=0.149)$ showed no publication bias (Fig. 4). Additionally, pooled HR was not significantly changed after removing individual studies. Therefore, our results were stable and reliable.

\section{Discussion}

VTE is a common and life-threatening condition that occurs in cancer patients [1][2]. Lung cancer is the leading cause of cancer-related death worldwide [6] and the incidence rate of VTE reaches $14 \%$ in lung cancer patients [28]. VTE leads to a higher risk of death, higher cost of treatment, and lower quality of life in NSCLC patients $[18,29,30]$. Factors related to the formation of VTE include individual factors and tumor-related factors. A large prospective study showed that elder patients had a 10-fold higher incidence of VTE relative to young patients [31]. Meanwhile, different gender can also be a risk factor for VTE [32, 33]. Additionally, a large retrospective study reported that [33] the highest rate of VTE (about 5\%) was observed in African American patients, while the lowest rate (3\%) was found in Asian/Pacific Islander patients. Surgery and chemotherapy have been shown to increase the risk of VTE as well. Cancer patients have a sixto seven-fold higher risk of developing chemotherapy-associated thrombosis [34]. Chemotherapy-related VTE was first identified in patients treated with cisplatin, a platinum-based drug that has been widely used in many cancers [35]. Other drugs such as tamoxifen, L-asparaginase, lenalidomide, immunosuppressive and cytotoxic drugs have also been reported to increase the risk of VTE [36]. Recent evidence has indicated that some oncogenic driver mutations in NSCLC are related to VTE, such as anaplastic lymphoma kinase (ALK) [25] and ROS-1[37].

In this meta-analysis, 12 articles were included, involving 6,360 NSCLC and 120 SCLC patients. SCLC is a type of lung cancer with completely different pathological features and biological behavior, as well as different treatment strategies. We first performed a heterogeneity test based on the above-mentioned VTE-related factors and found that the heterogeneity of this meta-analysis was high $(R=81 \%, P<0.01)$. The heterogeneity still existed after excluding the studies with SCLC patients. Also, there was still some heterogeneity in the Asian and non-Asian subgroups (data not shown). However, when studies with SCLC patients were removed, low heterogeneity was observed in the Asian subgroup. Since most of the studies included patients treated with chemotherapy, radiotherapy, and surgical treatment, we did not categorize them according to therapeutic regimens. Because of the high heterogeneity of the included studies, we used random-effects models for the analysis.

Our results showed that the OS of NSCLC patients with VTE was significantly shorter compared to those without VTE $(\mathrm{HR}=1.71,95 \% \mathrm{Cl}[1.39-2.10], P<0.01)$. We deleted studies by Lee et al. [19] and Kourelis et a./[18], which included patients with SCLC. The remaining studies were divided into two subgroups: Asian and non-Asian. The heterogeneity of the Asian subgroup significantly decreased $(R=35 \%, P=0.20)$. Both subgroups showed that NSCLC patients with VTE had shorter OS than those without VTE. The sensitivity analysis showed that studies contributing to the heterogeneity did not significantly affect the pooled results, suggesting that our results were statistically robust.

A cohort study compared the survival of cancer patients with or without VTE and observed a higher mortality rate in those who experienced VTE (OR $=2.20$, $95 \% \mathrm{Cl}$ [2.05-2.40]). The mortality ratio of patients who were diagnosed with cancer within one year after the diagnosis of VTE was 1.30 times (95\%Cl: $1.18-$ 1.42) higher relative to those without VTE [4]. Therefore, it is certain that VTE exerts a negative influence on the prognosis of cancer patients. A review involving 412,008 patients showed that $2.5 \%$ of them developed VTE and had a higher mortality compared to those without thrombotic events (HR $=1.38 ; 95 \%$ $\mathrm{Cl}$ [1.28-1.49]). Lung cancer patients had a 1.29-fold greater risk of mortality (95\% Cl [1.12-1.48]) when complicated with VTE [12], which was slightly lower than our results. It has also been shown that lung cancer patients with PE had significantly shorter survival compared to the control group (243.5 vs. 327 days, $p=0.01$ ), and a more significant difference was found in patients who were simultaneously diagnosed with PE and lung cancer [13].

Lung cancer is a very heterogeneous type of tumor disease, at a cellular and histological level[38]. The treatment strategies and prognostic outcomes of different lung cancer pathological types are very different. Lung cancer patients in a hypercoagulable state are related to the primary disease. The understanding of lung cancer heterogeneity is crucial to the awareness of the VTE implications and future developments regarding this field. For risk assessment of lung cancer patients with VTE, more targeted risk prediction models based on the pathological types should be explored, and corresponding molecular biomarkers should also be investigated.

However, our study has some limitations. First, we only reviewed English articles, which may lead to language bias. Second, data were extracted from the forms and converted to HR values, which may not accurately describe the original results. However, despite limitations, the study provides a clear understanding of management of NSCLC with VTE in clinical practice.

\section{Conclusions}

In summary, our meta-analysis showed that VTE had a significantly negative impact on the prognosis of NSCLC patients, especially Asian patients (HR for OS $=1.49 ; 95 \%[C l]=1.19-1.88)$. At present, multidisciplinary teams, including clinicians, nurses, and pharmacists, are increasingly involved in the overall management of cancer patients with VTE. It is of great importance to furtherly identify risk factors including pathological types, molecular heterogeneity, biomarkers, and therapeutic regimens for lung cancer with VTE for future investigations.

\section{Abbreviations}

NSCLC 
non-small cell lung cancer ; VTE:venous thromboembolism; DVT:deep vein thrombosis; PE:pulmonary embolism; PFS:progression-free survival; OS:overall survival; SCLC:small-cell lung cancer; ALK:anaplastic lymphoma kinase.

\section{Declarations}

\section{Acknowledgements}

Not applicable.

\section{Funding}

This work was supported by the Science Foundation of Peking University Cancer Hospital囚2020-27】.

\section{Availability of data and materials}

All data used for the systematic review and meta-analysis is present in the main manuscript in the Table.

\section{Ethics approval and consent to participate}

Ethical approval: This article does not contain any studies with human participants or animals performed by any of the authors.

\section{Consent for publication}

Written informed consent for publication was obtained from all participants.

\section{Competing interests}

No conflicts.

\section{References}

1. A T. Plegmasia alba dolens. Clin Med Deliv Hotel Paris. 1865;5:281-332.

2. Wun T, White RH. Venous thromboembolism (VTE) in patients with cancer: Epidemiology and risk factors. Cancer Invest. 2009;27:63-74.

3. Corrales-Rodriguez L, Blais N. Lung cancer associated venous thromboembolic disease: A comprehensive review. Lung Cancer. 2012. p. 1-8.

4. Sørensen HT, Mellemkjær L, Olsen JH, Baron JA. Prognosis of cancers associated with venous thromboembolism. N Engl J Med [Internet]. N Engl J Med; 2000 [cited 2020 Jul 1];343:1846-50. Available from: https://pubmed.ncbi.nlm.nih.gov/11117976/

5. Torre LA, Bray F, Siegel RL, Ferlay J, Lortet-Tieulent J, Jemal A. Global cancer statistics, 2012. CA Cancer J Clin. 2015;65:87-108.

6. Siegel RL, Miller KD, Jemal A. Cancer statistics, 2020. CA Cancer J Clin [Internet]. 2020;70:7-30. Available from: https://onlinelibrary.wiley.com/doi/abs/10.3322/caac.21590

7. Osmani L, Askin F, Gabrielson E, Li QK. Current WHO guidelines and the critical role of immunohistochemical markers in the subclassification of non-small cell lung carcinoma (NSCLC): Moving from targeted therapy to immunotherapy. Semin Cancer Biol. 2018;52:103-9.

8. Tagalakis V, Levi D, Agulnik JS, Cohen V, Kasymjanova G, Small D. High risk of deep vein thrombosis in patients with non-small cell lung cancer: A cohort study of 493 patients. J Thorac Oncol. 2007;2:729-34.

9. Hicks LK, Cheung MC, Ding K, Hasan B, Seymour L, Le Maître A, et al. Venous thromboembolism and nonsmall cell lung cancer: A pooled analysis of National Cancer Institute of Canada Clinical Trials Group trials. Cancer. 2009;115:5516-25.

10. Prandoni P, Lensing AWA, Piccioli A, Bernardi E, Simioni P, Girolami B, et al. Recurrent venous thromboembolism and bleeding complications during anticoagulant treatment in patients with cancer and venous thrombosis. Blood [Internet]. Blood; 2002 [cited 2020 Jun 30];100:3484-8. Available from: https://pubmed.ncbi.nlm.nih.gov/12393647/

11. Chew HK, Davies AM, Wun T, Harvey D, Zhou H, White RH. The incidence of venous thromboembolism among patients with primary lung cancer. $J$ Thromb Haemost [Internet]. American Medical Association; 2008 [cited 2020 Jul 1];6:601-8. Available from: https://pubmed.ncbi.nlm.nih.gov/16505267/

12. Anderson LA, Moore SC, Gridley G, Stone BJ, Landgren O. Concomitant and antecedent deep venous thrombosis and cancer survival in male US veterans. Leuk Lymphoma [Internet]. Leuk Lymphoma; 2011 [cited 2020 Jul 1];52:764-70. Available from: https://pubmed.ncbi.nlm.nih.gov/21271864/

13. Chuang YM, Yu CJ. Clinical characteristics and outcomes of lung cancer with pulmonary embolism. Oncology [Internet]. Oncology; 2008 [cited 2020 Jul 1];77:100-6. Available from: https://pubmed.ncbi.nlm.nih.gov/19622900/

14. Chen W, Zhang Y, Yang Y, Zhai Z, Wang C. Prognostic significance of arterial and venous thrombosis in resected specimens for non-small cell lung cancer. Thromb Res. 2015;136:451-5.

15. Fuentes HE, Oramas DM, Paz LH, Casanegra Al, Mansfield AS, Tafur AJ. Meta-analysis on anticoagulation and prevention of thrombosis and mortality among patients with lung cancer. Thromb Res [Internet]. 2017;154:28-34. Available from:

https://linkinghub.elsevier.com/retrieve/pii/S0049384817302505

16. Higgins JPT, Thompson SG, Deeks JJ, Altman DG. Measuring inconsistency in meta-analyses. Br Med J. 2003;327:557-60.

17. Tierney JF, Stewart LA, Ghersi D, Burdett S, Sydes MR. Practical methods for incorporating summary time-to-event data into meta-analysis. Trials [Internet]. 2007;8:16. Available from: http://www.ncbi.nlm.nih.gov/pubmed/17555582

Page $7 / 12$ 
18. Kourelis T V., Wysokinska EM, Wang Y, Yang P, Mansfield AS, Tafur AJ. Early venous thromboembolic events are associated with worse prognosis in patients with lung cancer. Lung Cancer [Internet]. 2014;86:358-62. Available from: https://linkinghub.elsevier.com/retrieve/pii/S0169500214004115

19. Lee JW, Cha SI, Jung CY, Choi W II, Jeon KN, Yoo SS, et al. Clinical course of pulmonary embolism in lung cancer patients. Respiration. Switzerland; 2009;78:42-8.

20. De Meis E, Pinheiro VR, Zamboni MM, Guedes MTS, Castilho IAM, Martinez MMK, et al. Clotting, immune system, and venous thrombosis in lung adenocarcinoma patients: A prospective study. Cancer Invest. England; 2009;27:989-97.

21. Zhang PP, Sun JW, Wang XY, Liu XM, Li K. Preoperative plasma D-dimer levels predict survival in patients with operable non-small cell lung cancer independently of venous thromboembolism. Eur J Surg Oncol. 2013;39:951-6.

22. Wang Z, Yan HH, Yang JJ, Wang BC, Chen HJ, Zhou Q, et al. Venous thromboembolism risk factors in Chinese non-small cell lung cancer patients. Support Care Cancer. 2014;23:635-41.

23. Li R, Hermann G, Baldini E, Chen A, Jackman D, Kozono D, et al. Advanced nodal stage predicts venous thromboembolism in patients with locally advanced non-small cell lung cancer. Lung Cancer. 2016;96:41-7.

24. Shen Q, Dong X, Tang X, Zhou J. Risk factors and prognosis value of venous thromboembolism in patients with advanced non-small cell lung cancer: A casecontrol study. J Thorac Dis. 2017;9:5068-74.

25. Zer A, Moskovitz M, Hwang DM, Hershko-Klement A, Fridel L, Korpanty GJ, et al. ALK-Rearranged Non-Small-Cell Lung Cancer Is Associated With a High Rate of Venous Thromboembolism. Clin Lung Cancer. United States; 2017;18:156-61.

26. Young K, Paz-Ares L, Thatcher N, Spigel DR, Shahidi J, Soldatenkova V, et al. Venous thromboembolism with EGFR monoclonal antibody necitumumab in stage IV non-small cell lung cancer: A retrospective cohort analysis. Thromb Res. England; 2018;167:50-6.

27. Herrero Rivera D, Nieto-Guerrero Gómez JM, Cacicedo Fernández de Bobadilla J, Delgado D, Rivin del Campo E, Praena-Fernández JM, et al. Cardiovascular disease and survival in non-small cell lung cancer: a multicenter prospective assessment. Clin Transl Oncol. Italy; 2019;21:1220-30.

28. Connolly GC, Dalal M, Lin J, Khorana AA. Incidence and predictors of venous thromboembolism (VTE) among ambulatory patients with lung cancer. Lung Cancer. Ireland; 2012;78:253-8.

29. Khorana AA, Dalal MR, Lin J, Connolly GC. Health care costs associated with venous thromboembolism in selected high-risk ambulatory patients with solid tumors undergoing chemotherapy in the United States. Clin Outcomes Res. 2013;5:101-8.

30. Khorana AA, Francis CW, Culakova E, Kuderer NM, Lyman GH. Thromboembolism is a leading cause of death in cancer patients receiving outpatient chemotherapy [10]. J Thromb Haemost [Internet]. 2007;5:632-4. Available from: http://doi.wiley.com/10.1111/j.1538-7836.2007.02374.x

31. Tsai AW, Cushman M, Rosamond WD, Heckbert SR, Polak JF, Folsom AR. Cardiovascular risk factors and venous thromboembolism incidence: The longitudinal investigation of thromboembolism etiology. Arch Intern Med. 2002;162:1182-9.

32. Khorana AA, Francis CW, Culakova E, Fisher RI, Kuderer NM, Lyman GH. Thromboembolism in hospitalized neutropenic cancer patients. J Clin Oncol. 2006;24:484-90.

33. Khorana AA, Francis CW, Culakova E, Kuderer NM, Lyman GH. Frequency, risk factors, and trends for venous thromboembolism among hospitalized cancer patients. Cancer [Internet]. 2007;110:2339-46. Available from: http://www.ncbi.nlm.nih.gov/pubmed/17918266

34. Khorana AA, Dalal M, Lin J, Connolly GC. Incidence and predictors of venous thromboembolism (VTE) among ambulatory high-risk cancer patients undergoing chemotherapy in the United States. Cancer. 2013;119:648-55.

35. Doll DC, List AF, Greco FA, Hainsworth JD, Hande KR, Johnson DH. Acute vascular ischemic events after cisplatin-based combination chemotherapy for germ-cell tumors of the testis. Ann Intern Med. 1986;105:48-51.

36. Heit JA. Epidemiology of venous thromboembolism. Nat Rev Cardiol. 2015;12:464-74.

37. Chiari R, Ricciuti B, Landi L, Morelli AM, Delmonte A, Spitaleri G, et al. ROS1-rearranged Non-small-cell Lung Cancer is Associated With a High Rate of Venous Thromboembolism: Analysis From a Phase II, Prospective, Multicenter, Two-arms Trial (METROS). Clin Lung Cancer. 2020;21:15-20.

38. Marino FZ, Bianco R, Accardo M, Ronchi A, Cozzolino I, Morgillo F, et al. Molecular heterogeneity in lung cancer: From mechanisms of origin to clinical implications. Int J Med Sci. 2019;

\section{Figures}


Records identified through database searching $(n=5095)$ : $345)$ and Cochrane $(n=77)$

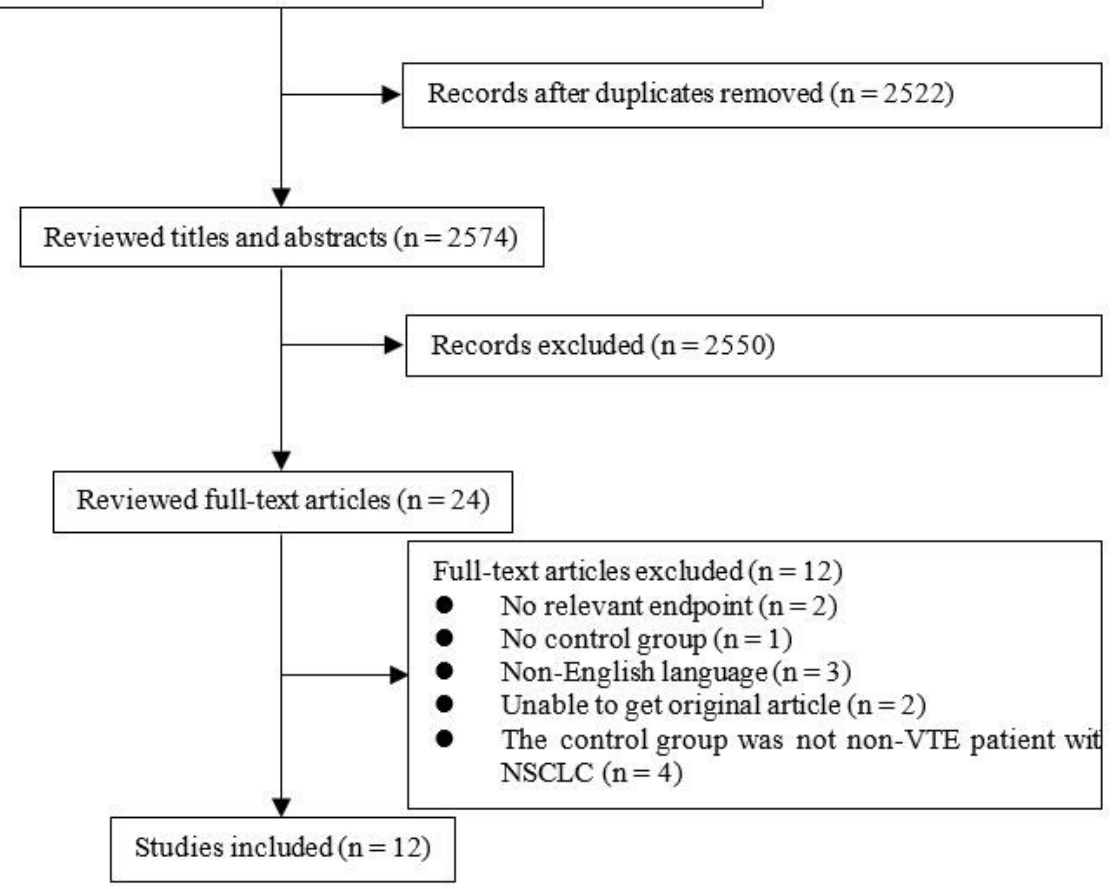

\section{Figure 1}

Flow diagram of the literature screening process

Records identified through database searching $(n=5095)$ :

PubMed ( $n=317)$, Embase $(n=4356)$, Web of Science $(n=$ $345)$ and Cochrane $(n=77)$

Additional literature identified through other sources $(\mathrm{n}=1)$

Records after duplicates removed $(\mathrm{n}=2522)$

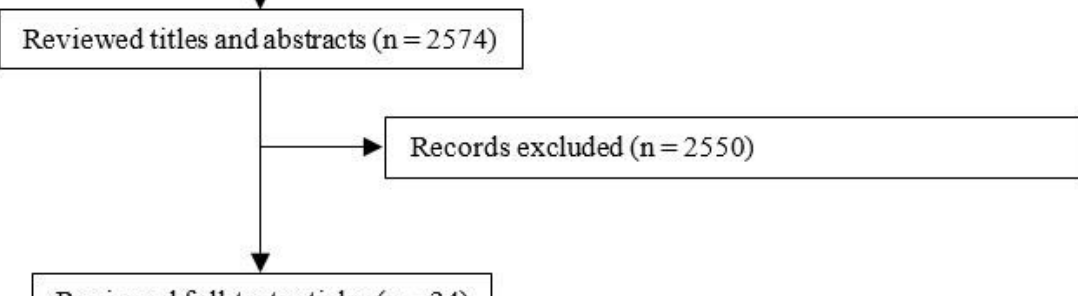

Reviewed full-text articles $(\mathrm{n}=24)$

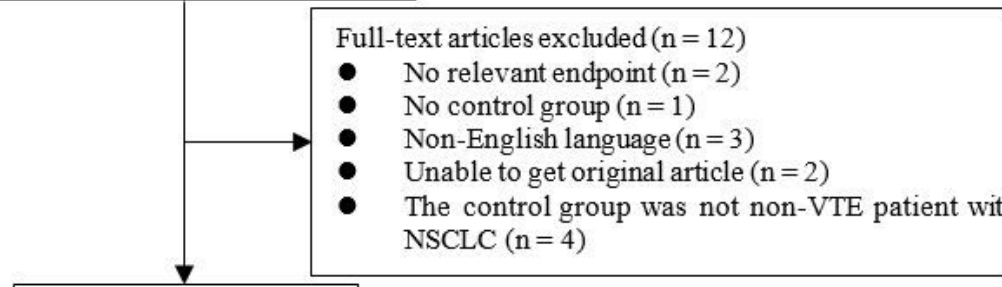

Studies included $(\mathrm{n}=12)$ 
Figure 1

Flow diagram of the literature screening process

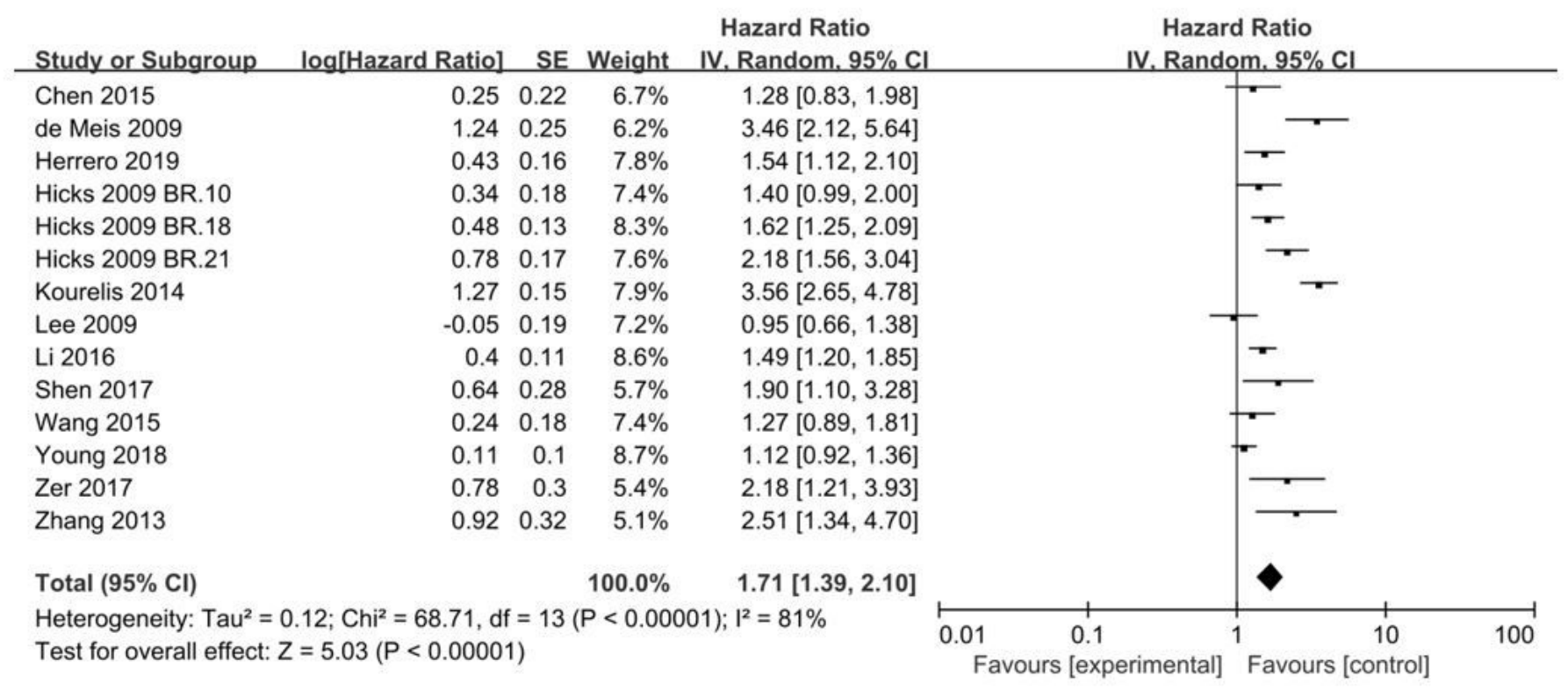

Figure 2

Forest plot was generated to compare the OS between NSCLC patients with and without VTE.

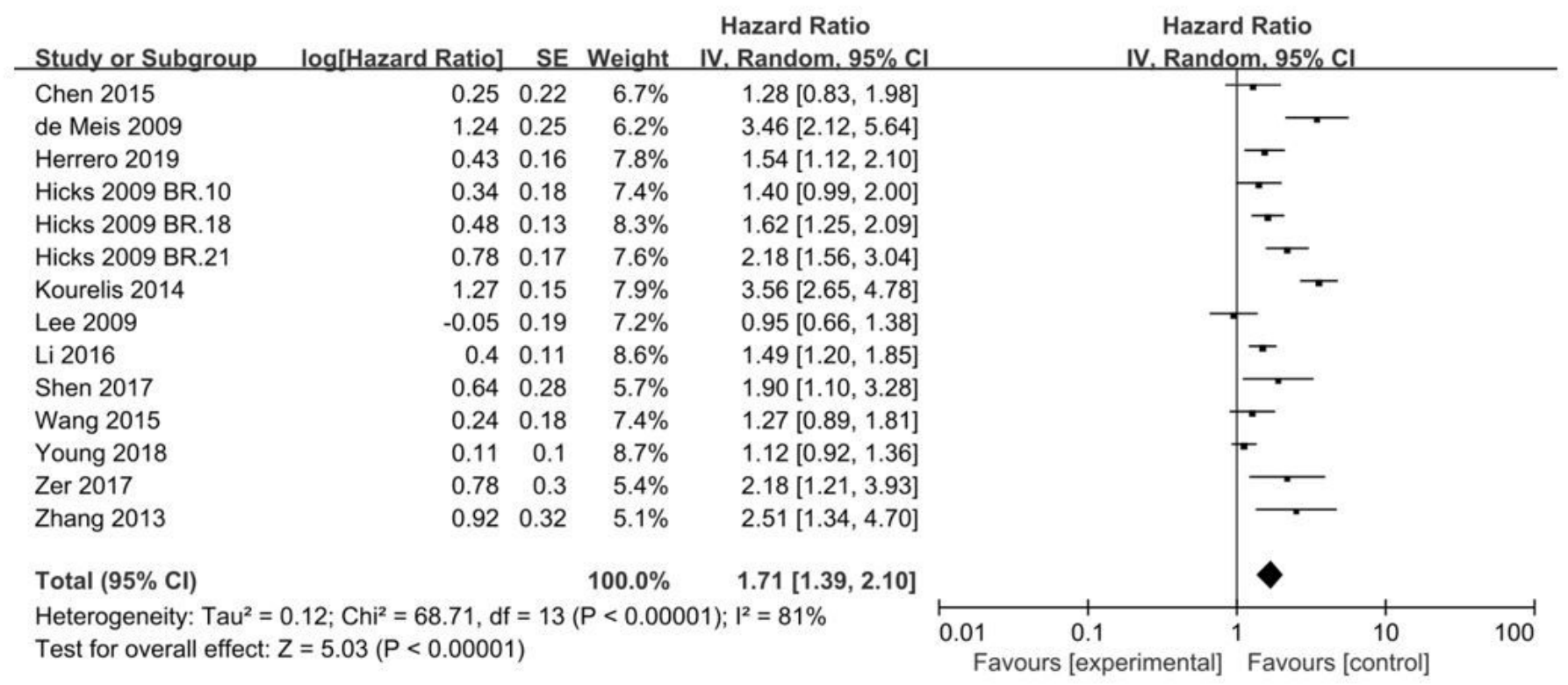

Figure 2

Forest plot was generated to compare the OS between NSCLC patients with and without VTE. 
Hazard Ratio Hazard Ratio

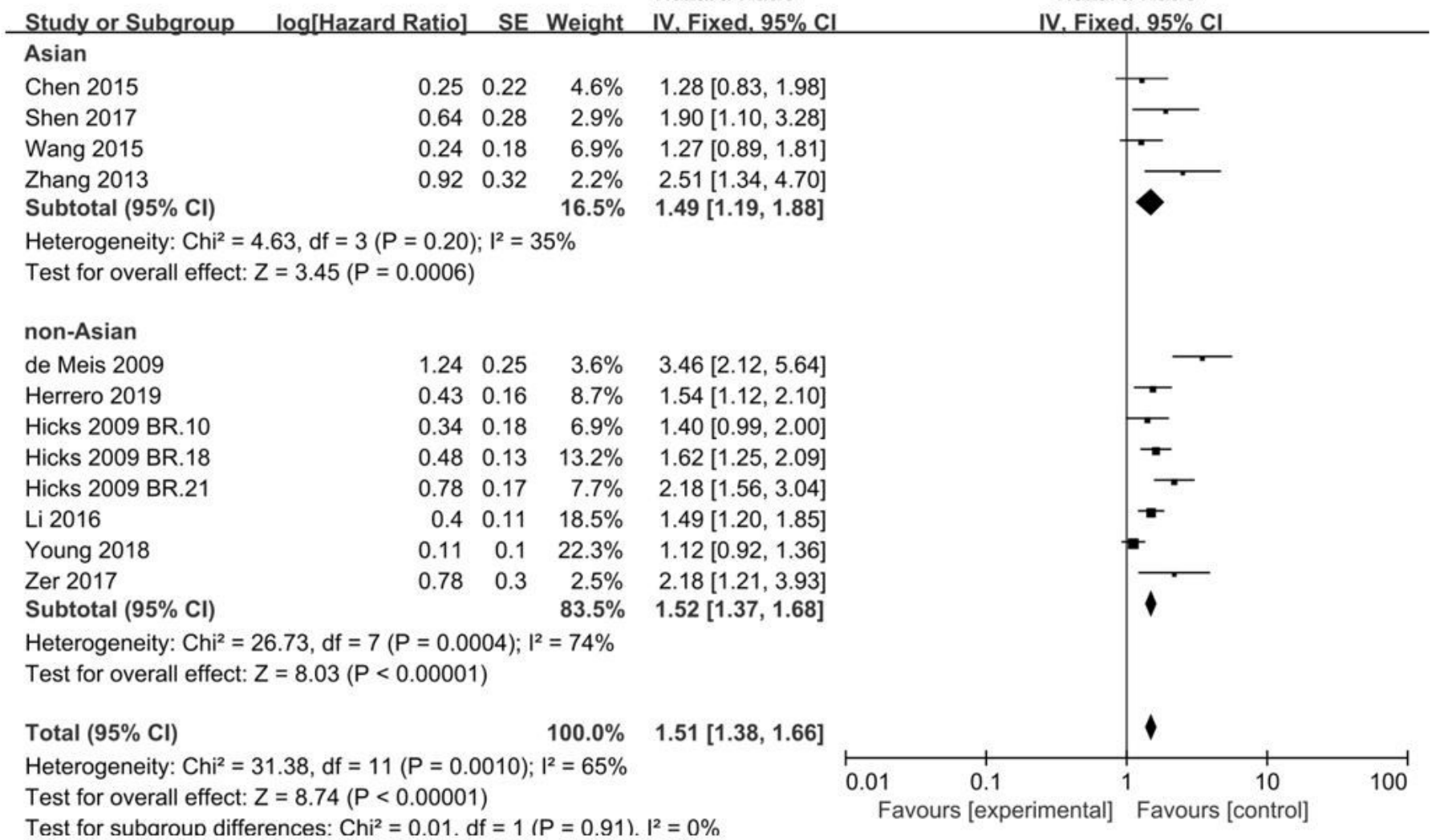

Figure 3

Forest plot was generated to compare the OS between NSCLC patients with and without VTE.

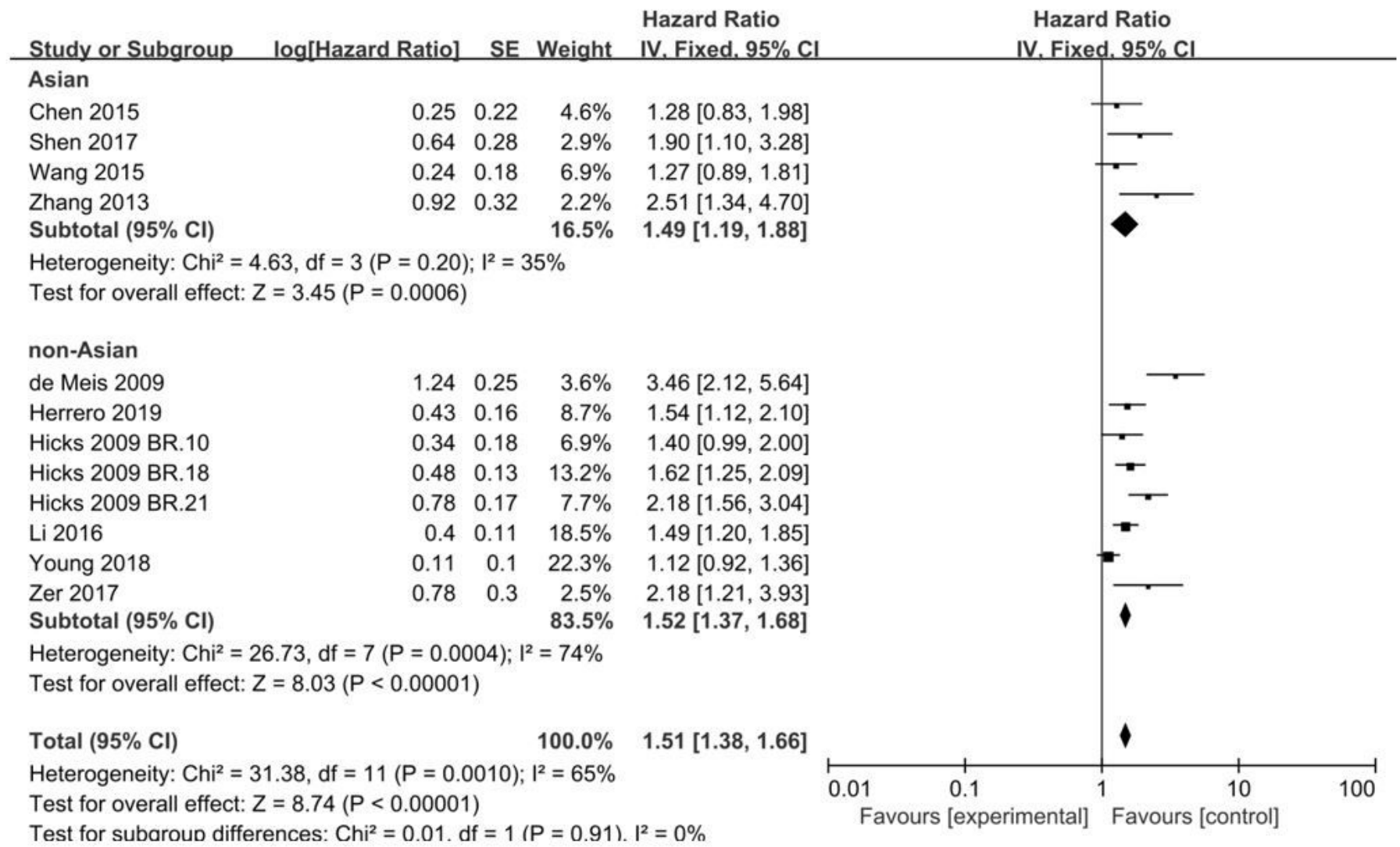

Figure 3 
a) Begg's funnel plot with pseudo $95 \%$ confidence limits

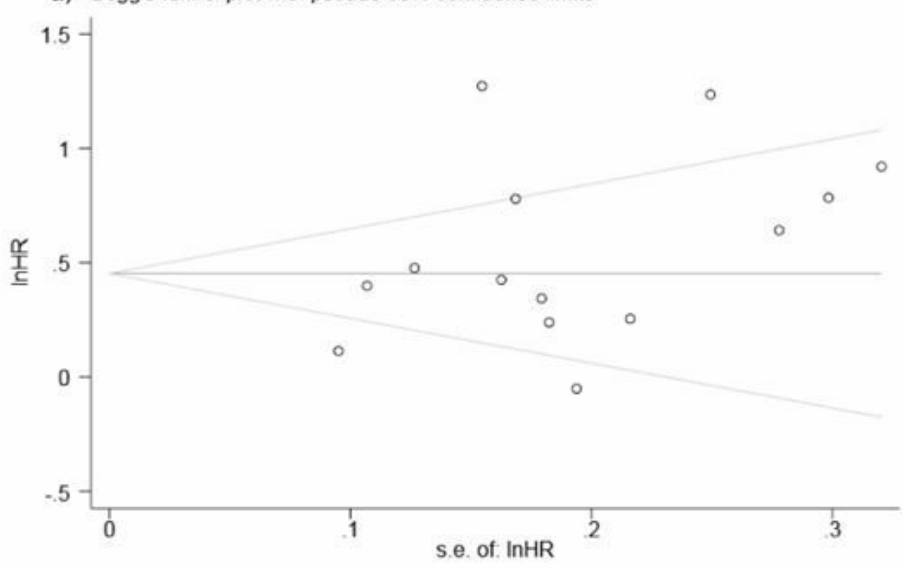

b) Meta-analysis estimates, given named study is omitted

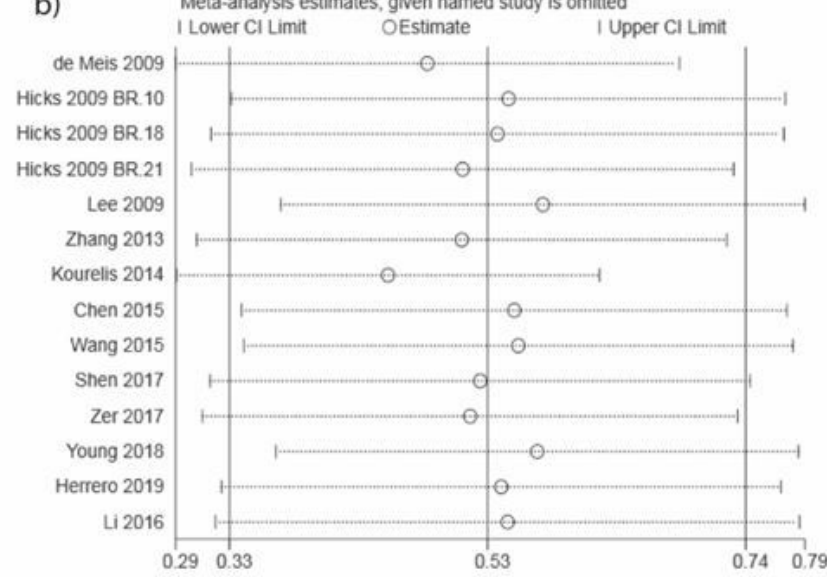

Figure 4

Publication bias and sensitivity analysis of OS between NSCLC patients with and without VTE). a) The Bag's funnel plot was applied to evaluate the publication bias in the meta-analysis; b) Sensitivity analysis was performed to assess the stability of the results.

a) Begg's funnel plot with pseudo $95 \%$ confidence limits

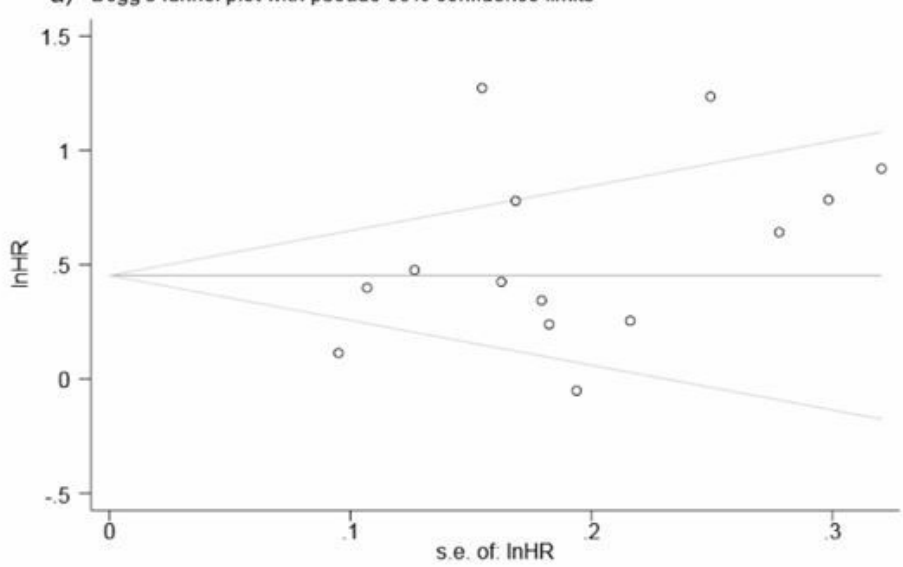

b) Meta-analysis estimates, given named study is omitted

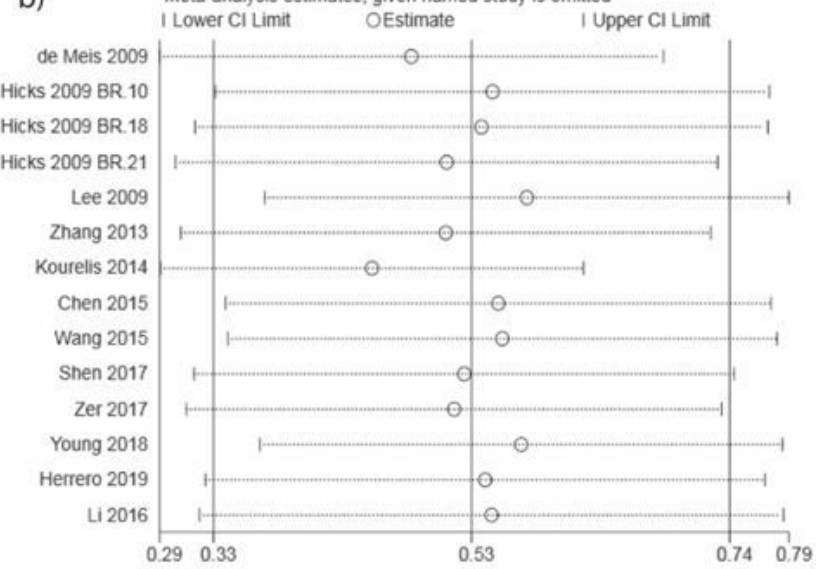

Figure 4

Publication bias and sensitivity analysis of OS between NSCLC patients with and without VTE). a) The Bag's funnel plot was applied to evaluate the publication bias in the meta-analysis; b) Sensitivity analysis was performed to assess the stability of the results. 